\title{
A New Topology of Interleaved Boost Converter for Electric Vehicle Applications
}

\author{
B. Sarath Kumar Reddy, P.V. Balasubramanyam
}

\begin{abstract}
This paper proposes battery based Interleaved boost converter (IBC), along with multilevel inverter(5-level) feeding the Permanent Magnet Synchronous Machine (PMSM)motor to drive the wheels of the electric vehicle system. From past few decades automobile engineering and power electronics engineering combinedly working to introduce high speed, efficient charging vehicle by overcoming the issues of environment caused by fuel drives. The heart of this system is dc-dc (IBC)converter, which increases dc voltage of battery to high level. The dc voltage converted to ac through inverter. The inverter modifies the dc source of IBC to ac through Pulse width modulation (PWM)technique, by using MOSFET switches in inverter. Finally, ac energy feeds the (PMSM)drive. The existing topology converter used one switch and single inductor with 0.5 duty ratio, whereas proposed topology fed with two switches and two inductors connected in parallel, which reduces the current ripples and size of inductor, there by circuit size also reduced. Here the duty ratio is maintained $>0.5$, which increases the voltage level of battery pack and maintains maximum power at output side. The results of the proposed circuit are verified through Digital simulation studies are carried out using $\operatorname{MATLAB}(R 2017 \mathrm{~b}) /$ Simulink software.
\end{abstract}

Keywords: Non-conventional source, Interleaved Boost Converter (IBC), Multilevel inverter, MOSFET, Permanent Magnet Synchronous Machine (PMSM)motor.

\section{INTRODUCTION}

Green vehicles are most rapidly coming into the automobile sector, to overcome the environmental drawbacks caused by fuel automobiles.

Green vehicles are environmentally friendly, which can't exhibit the pollutant gases, by the use of electrical vehicle, the power electronics role in automobile sector also very crucial. Due to these vehicles are depending on charging batteries sometimes it can't meet high power applications.

In this case the battery voltage should be increased by using new topology called boost converter to meet high power demand and also reduce the ripples in inductor input currents. Interleaved boost converter topology is employed [1] in which the duty cycle is 0.7 .

Primarily solar panel dc charges the battery for which MPPT terminology used to track maximum power at any instant of weather conditions around PV panel [2], the fuel cell is failed to operate at MPP level due to the complexity of electro-chemical reaction process, but cell working all the times at MPP by the use of MPPT algorithm [11], [12].

Revised Version Manuscript Received on August 19, 2019

B. Sarath Kumar Reddy, PG Scholar, Department of EEE, CMR College of Engineering \&Technology, Kandlakoya, Hyderabad, Telangana, India.(email: sarathkumar.battula@gmail.com)

P.V. Balasubramanyam, Professor, Dept of EEE, CMR College of Engineering \&Technology, Kandlakoya, Hyderabad, Telangana, India.
A novel soft switching method has been introduced for an interleaved boost converter, having low switching losses, practically not implemented [3], Soft switching extension in [16].

The highly efficient boost converter is employed for low power applications, to increase efficiency transformer less converter with switched capacitor and coupled inductor used with low duty cycle [4].

The boosted voltage (dc-dc) fed to the inverter (dc-ac) to feed the motor. Solar inverter with two-phase dc-dc converter verified, with this converter current shared and stress on the switches reduced [5]. The non-isolated IBC used for high voltage gain, lack of isolation transformer improves power density I.e., interleaved circuit allows, high efficiency over a broad range of operating situations [6].

For the interleaved boost converter signal flows modelling drawn to observe the output voltage regulation, if interleaved boost converter has $\mathrm{N}$ number of basic cells connected parallelly, then the phase difference of pulses in cycle is $2 * \pi * \mathrm{~N}$ [7]. To minimize the destabilization of PV system due to cloud and disturbances in radiation. Perturb and observe algorithm, incremental conductance algorithm, constant voltage $(\mathrm{CV})$, these algorithms allow to flow the maximum power point in a solar panel [8].

To replace the conventional IBC and overcome the duty ratio problem in IBC. A two-stage cascaded IBC used at high voltage ----[9]. To charge the electrical system and improve the efficiency of green system multiple inputs are employed but the task is all the inputs have to charge battery pack, which stores energy before feeding to drive system [10][13].

A review carried out to select the best components from existing ones, for a good performance of electric vehicles showed in [20][15] [18]. From these it is observed that, most of the battery dependent vehicles need to increase the battery voltage to reach maximum power demand.

Some of the used normal boost converter, which has high ripples in current, three level boost converters by which the efficiency reduced and complexity also increased.

So, two level interleaved boost converter meets the demand maximum by sharing current with duty ratio 0.7 (> $0.5)$. Here also multi-level inverter circuit is employed to connect DC-AC with low THD to feed the driving system.

The disadvantages of the analysis of boost converter for PMSM motor of Hybrid electric vehicle are:

- The output voltage of boost converter is less, current ripples are existing this not efficient for high power applications.

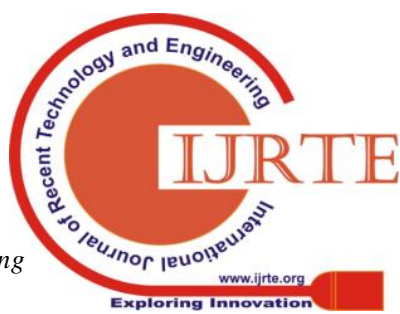


- Single switch terminology is implemented, stresses are more on this switch.

- The speed of the Permanent Magnet Synchronous motor is less in boost converter mode.

- High speed switching is used which increases switching losses. Thereby decrease efficiency.

\section{METHODOLOGY}

2.1 Analysis of boost converter fed to PMSM motor through three-level inverter:

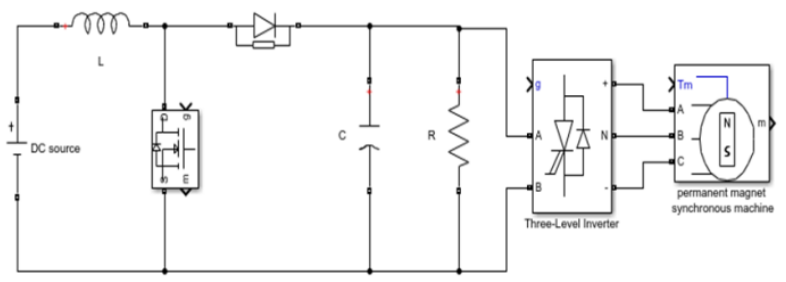

Figure 1: Boost converter fed PMSM motor through inverter

Figure 1. consists of dc voltage source of battery pack, and boost converter which boost up the battery voltage and Boost converter voltage fed to the 3-level inverter. The inverter converts dc voltage into ac through pulse width modulation technique. Hence the output of inverter feeds the PMSM motor, the motor used to drive the charging vehicle.

\subsection{Proposed Topology}

Case 1: Interleaved boost converter fed to PMSM motor through three-level inverter

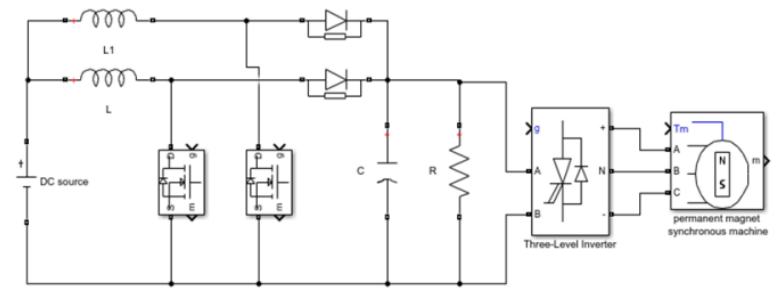

Figure 2: PMSM motor with interleaved boost converter

Fig 2. Consisting of dc source of battery pack, is connected to IBC (interleaved boost converter) consisting of two parallelly connected boost circuits. This interleaved connection of boost converter shares the ripples of input current through inductor.

The interleaved connection consisting of two switches S1 $\&$ S2. Which has duty ratio $0.7 \& 0.3$ respectively. The interleaved boost up voltage fed to the inverter.

The inverter is a topology which converts the dc output voltage of IBC to AC voltage by using the pulse width modulation technique. The converted $\mathrm{AC}$ voltage given to motor is supply.

Hence PMSM motor used to drive the wheel of the charging vehicle smoothly.

Case 2: interleaved boost converter fed to PMSM motor through 5-level inverter

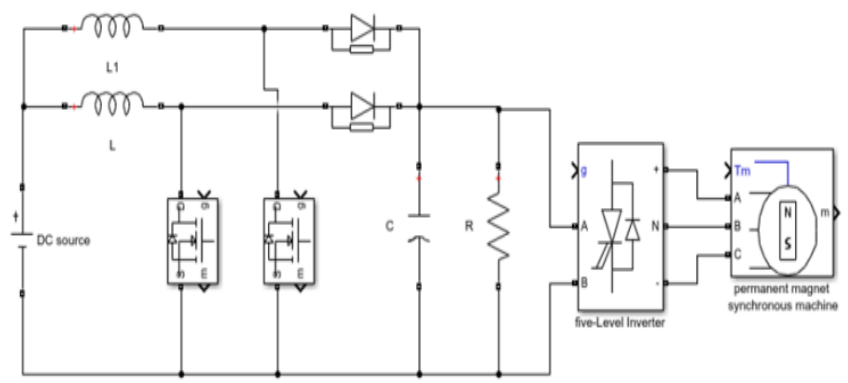

Fig 3. IBC fed to PMSM motor with 5-level inverter

Fig 3. Consisting of dc source of battery pack, is connected to IBC (interleaved boost converter) consisting of two parallelly connected boost circuits. This interleaved connection of boost converter shares the ripples of input current through inductor.

The interleaved connection consisting of two switches S1 $\&$ S2. Which has duty ratio $0.7 \& 0.3$ respectively. The interleaved boost up voltage fed to the inverter.

Hence the 3-level inverter increased to 5-level inverter, which consisting of two dc sources as input supply through cascaded switches and pulse width modulation and converted into ac supply. Using 5-level inverter get smooth sinusoidal waveform compared to 3-level inverter.

Advantages of the interleaved boost converter fed with PMSM motor through five level inverters:

- The output voltage of interleaved boost converter is increases and ripples of current also reduces

- Five-level inverter employed which improves the sinusoidal waveform by five stages.

- The speed characteristics of PMSM, motor is improved.

\section{SIMULATION CIRCUIT}

The fig 4 shows the simulation circuit of boost converter fed with PMSM; and 5(a). shows the output voltage of boost converter, 5(b). shows the stator currents, 5(c), (d)are speed and torque characteristics, with the simulation time period $0.1 \mathrm{sec}$ to1.0sec.

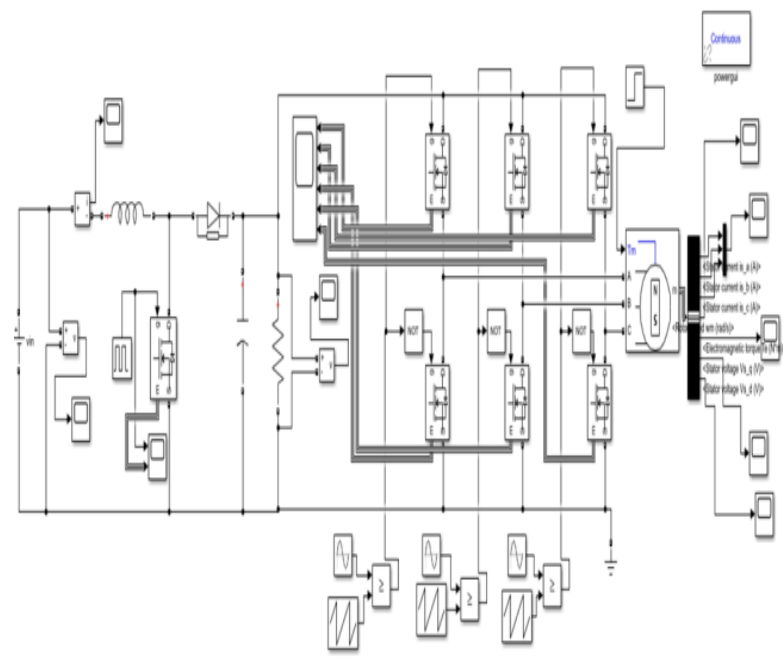

Figure 4: Simulink diagram of boost converter topology 


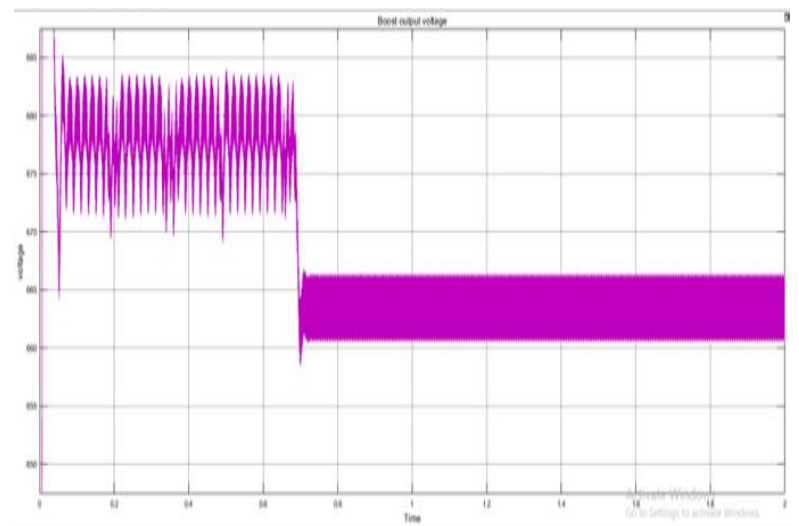

(a)

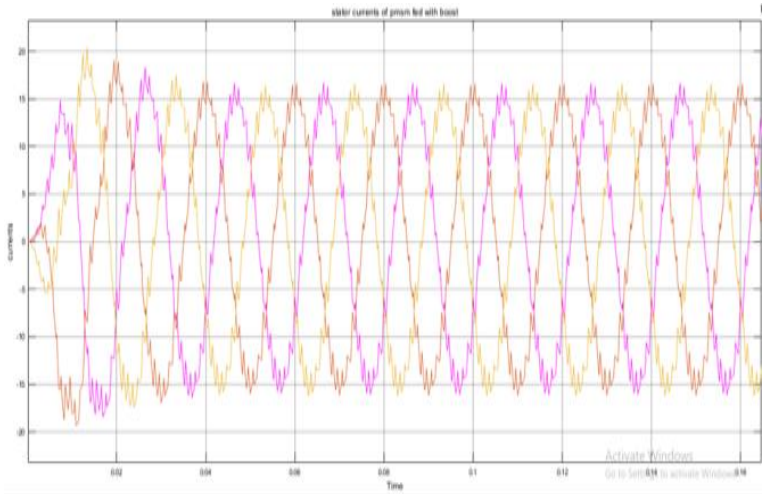

(b)

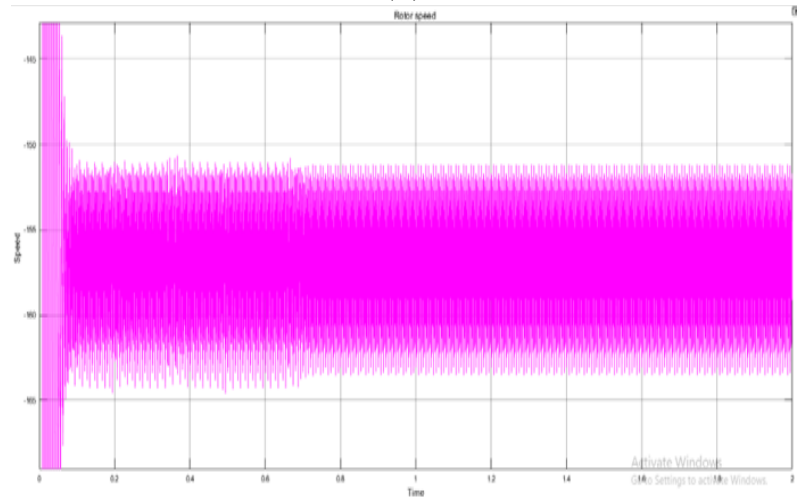

(c)

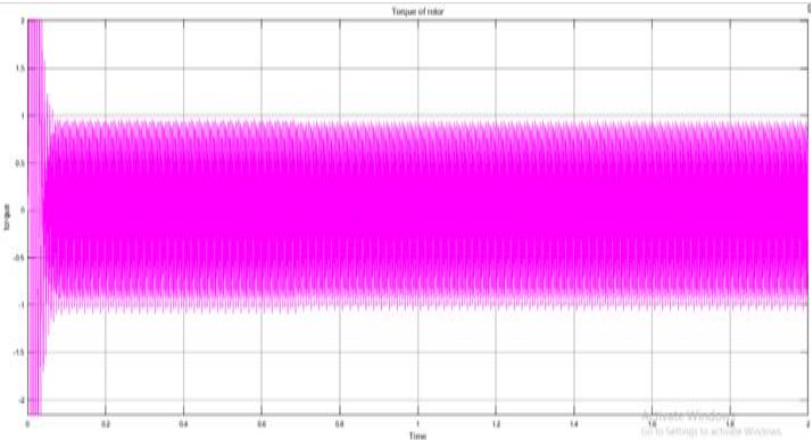

(d)

Fig 5. Waveform for (a) Boost converter output voltage (b) PMSM output stator currents (c) Speed \& (d) Torque characteristics of PMSM motor

Case 1: Interleaved boost converter fed to PMSM motor through three-level inverter:

Fig 6. Shows the Simulink diagram of interleaved boost converter fed PMSM motor through three-level inverter. Fig 7. shows the wave forms for proposed system a) interleaved boost output voltage, b) stator currents of Permanent magnet synchronous motor, c) speed and torque characteristics of PMSM motor.

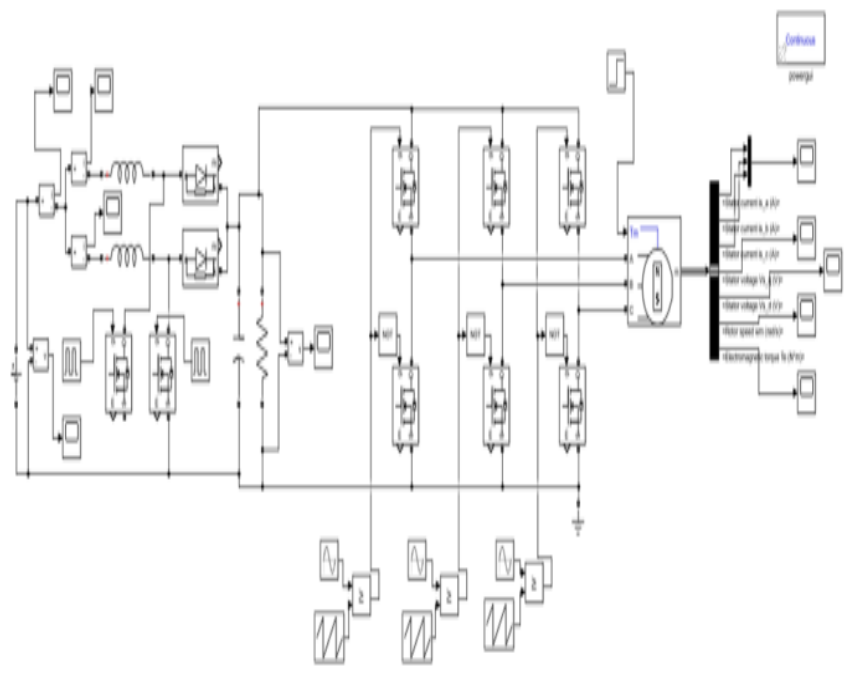

Fig.6 Simulink diagram of Interleaved boost converter fed to PMSM motor through three-level inverter

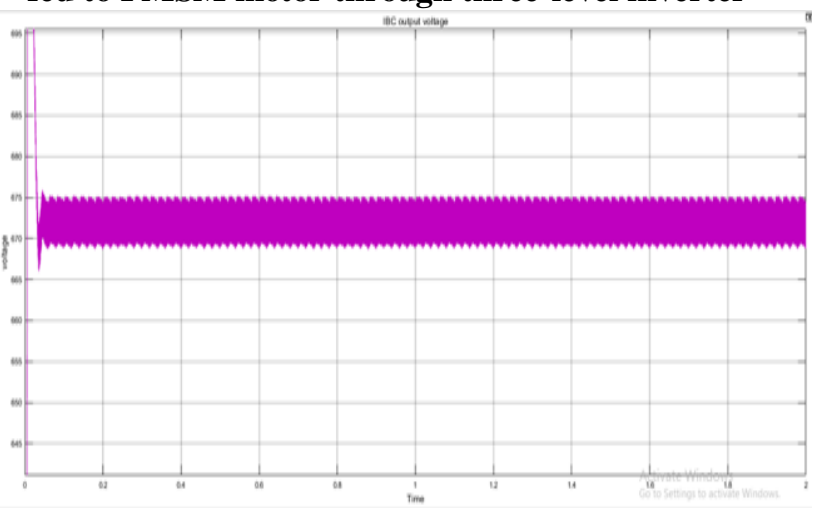

(a)

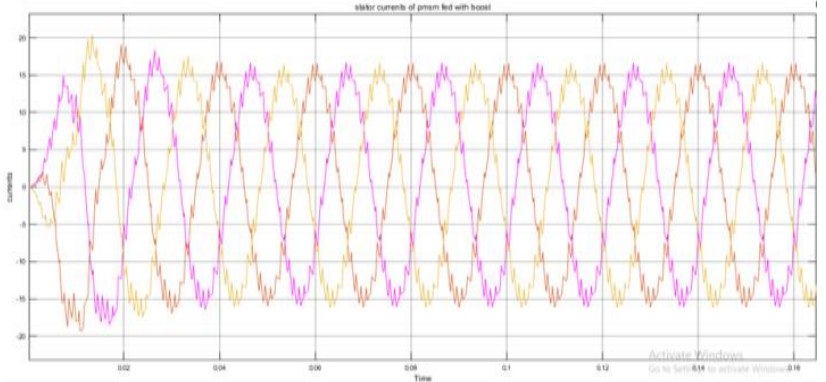

(b)

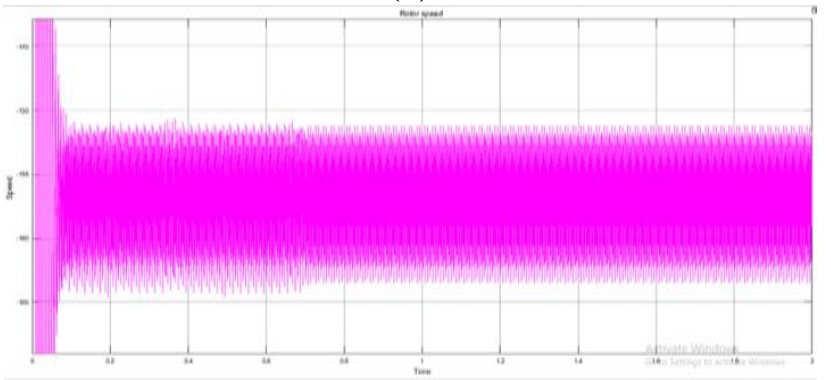

(c)

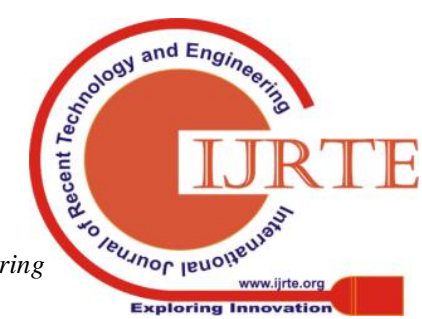




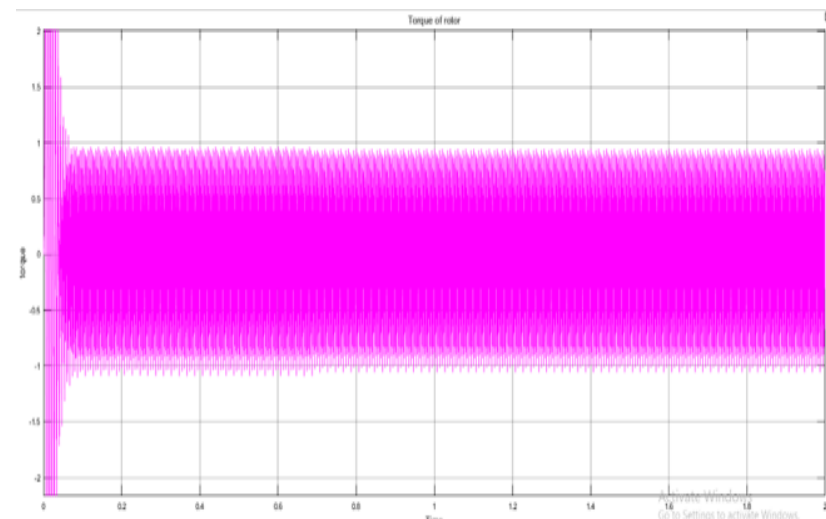

(d)

Fig.7 Waveform for (a) interleaved Boost converter output voltage (b) PMSM output stator currents (c) Speed \& (d) Torque characteristics of PMSM motor Initially there is some disturbances in the system due to friction in mechanical gears in electric vehicle and after some time duration will settled down.

Case 2: Interleaved boost converter fed to PMSM motor through 5-level inverter:

Fig 8. shows the Simulink diagram of interleaved boost converter fed to PMSM motor through five-level inverter. Fig 9. Shows the waveforms for case-2 a) interleaved boost output voltage for five-level inverter, b) stator currents of PMSM motor, c) torque and d) speed characteristics of PMSM motor.

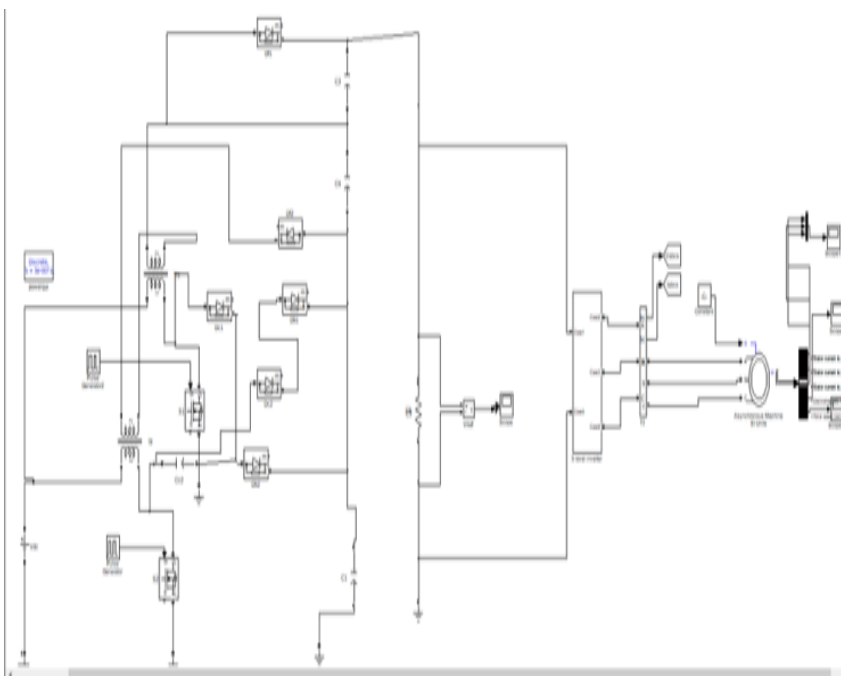

Fig 8. Simulink diagram of Interleaved boost converter fed to PMSM motor through 5-level inverter

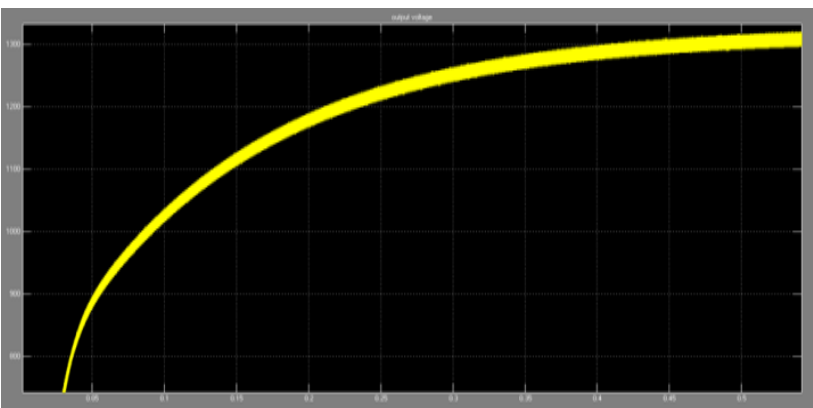

(a)

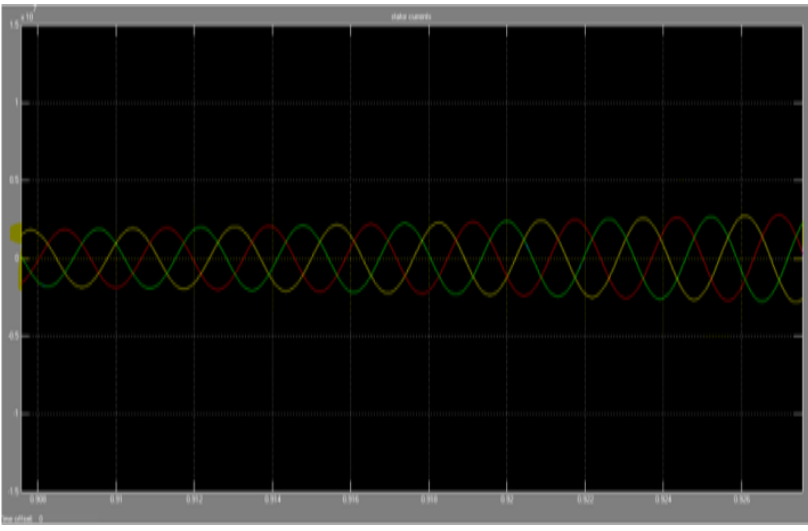

(b)

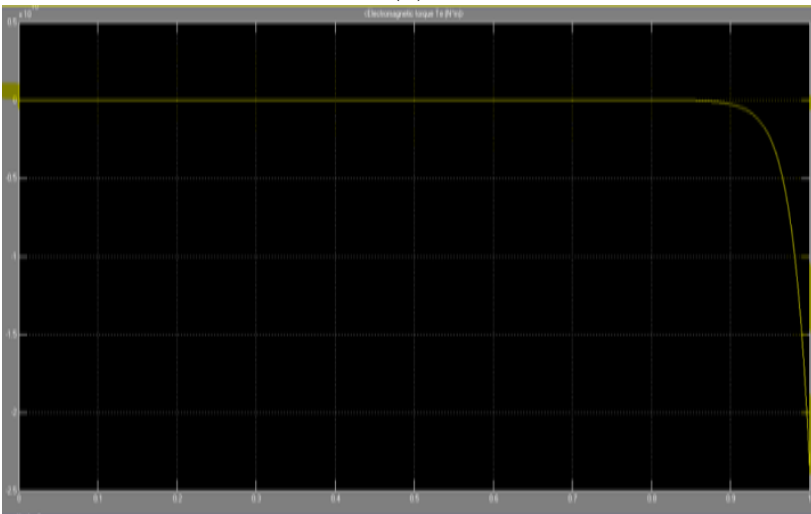

(c)

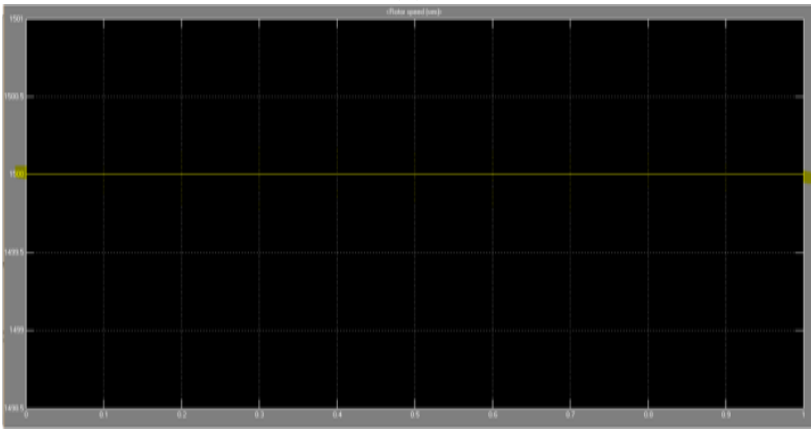

(d)

Fig.9 Waveform for (a) interleaved Boost converter output voltage (b) PMSM output stator currents (c) Torque \& (d) Speed characteristics of PMSM motor

\section{RESULTS AND DISCUSSION}

The table1 shows the parameter rating of the boost converter and interleaved boost converter for 3-level and 5-level inverter used for electric vehicle application.

TABLE 1: Parameter rating of Boost converter

\begin{tabular}{|l|l|l|}
\hline S.NO & Parameter & Rating \\
\hline 1 & Voltage & $210 \mathrm{~V}$ \\
\hline 2 & Inductor & $270 \mathrm{mH}$ \\
\hline 3 & Capacitor & $3000 \mu \mathrm{F}$ \\
\hline 4 & Resistor & $19.5 \Omega$ \\
\hline 5 & PMSM motor & $400 \mathrm{~V}, 3000 \mathrm{RPM}, 50 \mathrm{HZ}$ \\
\hline
\end{tabular}

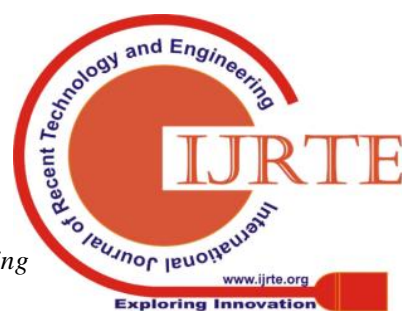


TABLE 2: Comparison of results

\begin{tabular}{|c|c|c|c|c|}
\hline \multirow{2}{*}{ S.No } & \multirow{2}{*}{ Parameter } & \multirow{2}{*}{$\begin{array}{l}\text { Eriting } \\
\text { system }\end{array}$} & \multicolumn{2}{|c|}{ Proposed system } \\
\hline & & & $\operatorname{coss}-1$ & $\operatorname{coss}-2$ \\
\hline 1. & luput $D C$ source & $210 \mathrm{~V}$ & $210 \mathrm{~V}$ & $210 \mathrm{~V}$ \\
\hline 2 & output volinge & $650 \mathrm{~V}$ & $660 \mathrm{~V}$ & $1100 \mathrm{~V}$ \\
\hline 3. & Speed & 1000rpm & $110 \mathrm{Orpm}$ & $15 \mathrm{Wrpm}$ \\
\hline
\end{tabular}

The table2 shows comparing results for boost converter and interleaved boost converter with 3-level and 5-level inverter. Case- 1 shows the interleaved boost converter with 3-level inverter and case- 2 shows the interleaved boost converter with 5-level.

\section{CONCLUSION}

This paper proposed an interleaved boost converter (dc-dc) with less current ripples in inductors. The existing system consisting of boost converter which boost up voltage but inductor current ripples are appeared considerably and three level inverters but the modified circuit consisting of IBC and 5 level inverter which reduces inductor current ripples and improves current waveform fed to motor respectively. This extension system is applicable to charging vehicles like electric cars. For the same input dc voltage, the speed of motor and output voltage of interleaved boost converter increased.

\section{REFERENCES}

1. Arpita Moon, Prof. (Mrs.) B.S.Dani and Rahul Argelwar "Analysis of Boost converter and Interleaved Converter for Permanent Magnet Synchronous Motor of Hybrid Electrical Vehicle" International Conference on Electrical, Electronics and Optimization Techniques (ICEEOT) - 2016.

2. Sarita Samal, Makireddi Ramana, Prasanta Kumar Barik "Modelling and Simulation of Interleaved Boost Converter with MPPT for Fuel Cell Application" IEEE International Conference on Technologies for Smart-City Energy Security and Power (ICSESP-2018), March 28-30, 2018, Bhubaneswar, India

3. Ashish Tiwari,Omprakash jaga, Shaktisingh soni,"Sliding Mode Controller Based Interleaved Boost Converter for Fuel Cell System" 2017 IEEE

4. Sayed Mokhtar Gheasaryan, Emad Roshandel, Sayed Morteza Saghaian-Nejad, "Proposing an Interleaved Boost Converter with Novel Soft Switching Approach in Photovoltaic Applications" 2017 IEEE 4th International Conference on Knowledge-Based Engineering and Innovation (KBEI) Dec. 22nd, 2017, ran University of Science and Technology) - Tehran, Iran

5. V.Senthil Nayagam and L.Premalatha, "Implementation of High Voltage Gain Interleaved Boost Converter Combined with Switched Capacitor for the Low Power Application" 2016 International Conference on Computation of Power, Energy Information and Communication (ICCPEIC)

6. B.chandra shekar, G.yoganjula reddy, Sanjay lakshminarayan, R. Sudhir Kumar, "Design, simulation and Validation of Solar Inverter with Two Phase Interleaved Boost Converter" 2015 IEEE

7. Musbahu Muhammad, Matthew Armstrong, and
Mohammed A. Elgendy "A Nonisolated Interleaved Boost Converter for High-Voltage Gain Applications" IEEE Journal Of Emerging And Selected Topics In Power Electronics, Vol. 04, No. 2, June 2016

8. Majid Abbasi, Ahmad Afifi, Mohammad Reza Alizadeh Pahlavani, "Signal Flow Graph and Dosturbance Obsorver based Output Voltage Regulation of an Interleaved Boost Converter" 7th Power Electronics, Drives Systems \& Technologies Conference (PEDSTC 2016), Iran University of Science and Technology, Tehran, Iran

9. Julian Valbuena G., Eduardo Mojica-Nava, "Digital Control for an Interleaved Boost Converter in a DC Microgrid" 2016 IEEE University of National Colombia Department of Electrical \&Electronics Engineering

10. Ambika.G.Dath, PrasannaKumar, Divya.S, "DESIGN AND MODELING OF A NOVEL TWO - STAGE CASCADED INTERLEAVED BOOST CONVERTER FOR HIGH VOLTAGE APPLICATIONS" Michael Faraday IET International Summit: MFIIS-2015, September 12-13, 2015, Kolkata, India (Paper ID: 83)

11. Rashmi G. Kale, Ashish A. Nilangekar, "Implementation of Multiple Input and Multiple Output Boost Converter for Electric Vehicle Charging System" 2017 International Conference onNascent Technologies in the Engineering Field (ICNTE-2017)

12. S. Sheik Mohammed, D. Devaraj, "Simulation of Incremental Conductance MPPT based Two Phase Interleaved Boost Converter using MATLAB/Simulink" 978-1-4799-6085-9/15/\$31.00 @2015 IEEE

13. Tian Xue, Zheng Minxin` and Yang Songtao, "Maximum Power Point Tracking for Photovoltaic Power Based on the Improved Interleaved Boost Converter"2016 IEEE 11th Conference on Industrial Electronics and Applications (ICIEA)

14. Ashish A.Nilangekar\&Rashmi G.kale, "Design and Development of Electric Vehicle Battery Charging Using MIMO Boost Converter"2016 Online International Conference on Green Engineering and Technologies (IC-GET)

15. Ahmed M. Omara \& M. Slepstov, "Bidirectional Interleaved DC/DC Converter for Electric Vehicle Application"IFOST-2016: Mechatronics, Electrical Engineering and Power Electronics

16. Archana R., Nikhar S. \&M. APTE Rahul Somalwar, "Review of Various Control Techniques for Dc-Dc Interleaved Boost Converters"2016 International Conference on Global Trends in Signal Processing, Information Computing and Communication

17. M. R. Ahmed, R. Todd and A. J. Forsyth, "Extended Soft-switching Operation of the Dual Interleaved Boost Converter" 2016 IEEE

18. Dr.Sreekala.k, Nithin Shaji, "Fuzzy Controlled Power Factor Correction in AC/DC Interleaved Boost Converter" 2016 International Conference on Circuit, Power and Computing Technologies [ICCPCT]

19. Kasan Hemasuk , Sakorn Po-Ngam, "The Simplified Regenerative Boost Converter for Electric Vehicle Applications" 5th International Electrical Engineering Congress, Pattaya, Thailand, 8-10 March 2017

20. Ashish Tiwari, Om Prakash Jaga, "Component Selection For An Electric Vehicle: A Review" 2017 International Conference on Computation of Power, Energy, Information and Communication (ICCPEIC). 